\title{
On the Non-Identity between Prime Matter and Potency in Siger of Brabant's Metaphysics
}

\author{
Andrew LaZella \\ University of Scranton
}

\begin{abstract}
To avoid reification of prime matter, or the indeterminate, yet determinable, substrate underlying all change, many readers of Aristotle have identified this per se unknowable "stuff" with its functional identity, i.e., as a conceptual placeholder of the sum of formal potencies abstracted from concrete particulars. Despite the appeal of this reduction, a case will be made in reference to Siger of Brabant's Metaphysics for the irreducibility of prime matter. This entails granting an extra-formal reality to prime matter beyond its functional role as a correlate passively receiving forms imparted by an agent without contributing anything of this own.

Key words: Siger of Brabant, metaphysics, prime matter, potencie.
\end{abstract}

\begin{abstract}
Para evitar la "reificación" de la materia prima, o del sustrato indeterminado pero determinable, que subyace a todo cambio, muchos lectores de Aristóteles han identificado a esta "cosa" incognoscible per se con su identidad funcional, es decir, como un marcador conceptual que sostiene la suma de las potencias formales abstraídas a partir de particulares concretos. A pesar de lo atractivo de esta reducción, se presentará una defensa de la irreductibilidad de la materia prima a partir de la Metafísica de Siger de Brabante. Esto implica otorgar a la materia prima una realidad
\end{abstract}

Recibido: I4 - IO - IO . Aceptado: I9 - II - IO.

Tópicos 39 (2010), 
"extra formal" que rebasa su papel funcional como un correlato que recibe pasivamente las formas de un agente sin aportar nada ella misma.

Palabras clave: Siger de Brabante, metafisica, materia prima, potencia.

\section{Introduction}

The question of prime matter goes back at least as far as Aristotle's Metaphysics. As the name suggests, "prote hule" is that "wood-like stuff" underlying all change. Thus, Aristotle can maintain against Heraclitean flux that the being of becoming need not undergo a radical ceasing to be at each moment followed by an inexplicable emergence of something radically new in its place. Nor must he follow Parmenides and Plato in seeking a principle of stability transcending the flux of appearances. Instead, there is a "wood-like stuff" capable of being shaped and reshaped throughout even the most radical change thereby grounding disparate appearances in an underlying identity.

This description, however, does not adequately account for what underlies the change: to call such stuff "wood-like" is to borrow a name from the order of forms in attempt to identify that which does not and cannot appear as form. This would leave our account of fundamental reality in the hands of analogical description, borrowing imagery from the world of appearance to apply to reality itself. Just as the same wood-stuff underlies this tree and that table and the change that takes place between them, so too when we reach the elemental level, some wood-like stuff underlies elemental change, such as when earth becomes fire, or water becomes air. If our account of this ontological fundament can only describe such change using images from the world of experience, positing an indeterminate wood-like stuff beneath all change, our philosophical logos seems to suffer a reversion to mythical theogony, a description without account of the procession of everything from a primordial chaos, the formless and indeterminate void from whence the recognizable figures of experience come to be formed.

To quell the unthinkable nature of something lacking any determination, many medieval Aristotelians would favor a concept of prime matter as pure potency, a sort of relative limit concept without an ontological status of its own. All determination comes from form. Matter provides determinability, but is nothing apart from its determinations. With Aquinas in particular, one finds a con- 
vincing defense of this "matter as potency" thesis. ${ }^{I}$ In those things lacking a necessity of being, that is in all hylomorphic composites, their power of being (virtus essendi) follows form's victory over matter. ${ }^{2}$ For there to be hylomorphic unity, form must conquer (vincit) matter. ${ }^{3}$ Thus, any change requires a contest between conquering form and conquered matter. Fire burning a log must overcome the resistance of wood, which does not give way to the invading form

\footnotetext{
I See Norbert LuYten: "Matter as Potency", The Concept of Matter, ed. Ernan McMullin, Notre Dame: University of Notre Dame Press, I963, pgs. I22-I33, from whom I borrow this term.

2 "Ex his autem principiis, secundum quod sunt essendi principia, tripliciter sumitur necessitas absoluta in rebus. Uno quidem modo, per ordinem ad esse eius cuius sunt. Et quia materia, secundum id quod est, ens in potentia est; quod autem potest esse, potest etiam et non esse: ex ordine materiae necessario res aliquae corruptibiles existunt; sicut animal quia ex contrariis compositum est, et ignis quia eius materia est contrariorum susceptiva. Forma autem, secundum id quod est, actus est: et per eam res actu existunt. Unde ex ipsa provenit necessitas ad esse in quibusdam. Quod contingit vel quia res illae sunt formae non in materia: et sic non inest ei potentia ad non esse, sed per suam formam semper sunt in virtute essendi; sicut est in substantiis separatis. Vel quia formae earum sua perfectione adaequant totam potentiam materiae, ut sic non remaneat potentia ad aliam formam, nec per consequens ad non esse: sicut est in corporibus caelestibus. In quibus vero forma non complet totam potentiam materiae, remanet adhuc in materia potentia ad aliam formam. Et ideo non est in eis necessitas essendi, sed virtus essendi consequitur in eis victoriam formae super materia: ut patet in elementis et elementatis. Forma enim elementi non attingit materiam secundum totum eius posse: non enim fit susceptiva formae elementi unius nisi per hoc quod subiicitur alteri parti contrarietatis. Forma vero mixti attingit materiam secundum quod disponitur per determinatum modum mixtionis. Idem autem subiectum oportet esse contrariorum et mediorum omnium, quae sunt ex commixtione extremorum. Unde manifestum est quod omnia quae vel contrarium habent vel ex contrariis sunt, corruptibilia sunt. Quae autem huiusmodi non sunt, sempiterna sunt: nisi per accidens corrumpantur, sicut formae quae non subsistunt sed esse earum est per hoc quod insunt materiae." S. Thomae Aquinatis: Liber de veritate catholicae Fidei contra errores infidelium seu Summa contra Gentiles, t. 2-3, ed. P. Marc, C. Pera, and P. Caramello, Taurini-Romae: Marietti I96I, II. 30. Hereafter "SCG."

3 "Non autem minus est aliquid unum ex substantia intellectuali et materia corporali quam ex forma ignis et eius materia, sed forte magis: quia quanto forma magis vincit materiam, ex ea et materia efficitur magis unum.Quamvis autem sit unum esse formae et materiae, non tamen oportet quod materia semper adaequet esse formae. Immo, quanto forma est nobilior, tanto in suo esse superexcedit materiam. Quod patet inspicienti operationes formarum, ex quarum consideratione earum naturas cognoscimus: unumquodque enim operatur secundum quod est. Unde forma cuius operatio superexcedit conditionem materiae, et ipsa secundum dignitatem sui esse superexcedit materiam."'SCG II.68.
} 
without a fight. In the case of the human substance, the incorporeal form is the substantial form of the body, thus requiring the former to win an even greater victory than, for example, the form of fire, in order to effect the complex unity of a human substance.

But in assessing Aquinas's claim, we must be careful to understand the relation between form and matter. Form's conquest of matter does not meet resistance from matter itself, but from other forms currently occupying the matter. Thus, wool cannot be conquered by the form of saw on account of the form of wool. To extend Aquinas's image, we might say that matter (both primary and secondary) provides the battlefield upon which forms compete and yet itself offers nothing in the way of resistance. ${ }^{4}$ Diverse matters have diverse determinability because they are informed by different forms. ${ }^{5}$ Thus, any hylomorphic being's power of being (virtus essendi) is contingent because new forms are always competing to occupy the same matter. ${ }^{6}$ Prime matter, furthermore, is what we call the full slate of formal possibilities, a sort of mirror image divorced

4 "Sciendum est tamen quod, cum Avicebron sic argumentatur, est aliquid quod est movens non motum, scilicet primus factor rerum, ergo, ex opposito, est aliquid quod est motum et patiens tantum [m.e.], quod concedendum est. Sed hoc est materia prima, quae est potentia pura, sicut Deus est actus purus [m.e.]. Corpus autem componitur ex potentia et actu, et ideo est agens et patiens." Sancti Thomae Aquinatis: Opera omnia iussu impensaque Leonis XIII P. M. edita, t. 4-5: Pars prima Summae theologiae, Ex Typographia Polyglotta S. C. de Propaganda Fide: Romae I888-I889, I, q. I I5, a. I, ad 2. Hereafter "ST."

5 Aquinas argues that matter per se is in potency to all forms, yet its reception of forms is ordered according to hierarchical degrees of complexity. Thus, something of a higher order cannot emerge immediately from something of a lower order (e.g., a human from mud), although presumably such is possible through gradual stages of increased complication. Aquinas states: "Quamvis autem generatio fiat ex non ente quod est in potentia, non tamen fit quodlibet ex quocumque; sed diversa fiunt ex diversis materiis. Unumquodque enim generabilium habet materiam determinatam ex qua fit, quia formam oportet esse proportionatam materiae. Licet enim materia prima sit in potentia ad omnes formas, tamen quodam ordine suscipit eas. Per prius enim est in potentia ad formas elementares, et eis mediantibus secundum diversas proportiones commixtionum est in potentia ad diversas formas [m.e.]: unde non potest ex quolibet immediate fieri quodlibet, nisi forte per resolutionem in primam materiam." S. Thomae Aquinatis: In duodecim libros Metaphysicorum Aristotelis expositio, ed. M.R. Cathala, R.M. Spiazzi, $2^{a}$ ed., Taurini-Romae: Marietti I97I, lib. I2, 1. 2, n. I5. It should be noted, however, that this ordering does not take place on the part of matter, but on the part of form. Although matter is available for all forms, a human cannot come to be from mud because of the substantial form of mud, not because of its matter. Remember, matter is "patiens tantum." See n. 4 above.

${ }^{6}$ See SCG II. 30 and n. 2 above. 
in thought from all actual content or determination. If everything appears and can be identified on the basis of form, or what can be formed or shaped out of a given material, then matter both primary and secondary is only the shapeable or formable stuff corresponding to all change, determinable and yet itself nothing apart from any determination. The reduction of prime matter to a mere abstraction, a pure slate of determinability distinguished in mente from all actual determination, saves philosophical thought from reifying such per se unintelligible stuff.

There is, however, another fate for prime matter in the Middle Ages. ${ }^{7}$ As we will see, a contemporary of Aquinas', Siger of Brabant, complicates this clean reduction of matter to potency by calling into question the traditional image of matter as the underlying raw material of change, a model he links to artificial production. In his four "reports" on Aristotle's Metaphysics, the Cambridge, Paris, Munich and Vienna Reports, named after their respective manuscript libraries, Siger rejects the claim that prime matter can simply be identified with potency. ${ }^{8}$ Although matter only ever appears on the basis of form and is understood in relation to the enactment of a given form (i.e., as potency to some form), matter qua matter must be granted an ontological status non-identical to its role as potency to form. This does not mean prime matter ever exists on its own apart

${ }^{7}$ Allan Wolter points to a number of other scholastics who reject the matter as potency thesis, mostly thinkers in the Franciscan tradition (e.g., William of Ware, Duns Scotus, and Ockham). He argues that although John Peckham also adopted such a view, his reasons were on account of Augustinian "seminal reasons," which Ware, Scotus, and Ockham reject. Their defense of actuality of matter is in keeping with divine omnipotence, such that it must be maintained that God could create prime matter without any form. Thus, given this extra-formal actuality of prime matter, a real distinction holds between form and matter. See Allan B. Wolter: "The Ockhamist Critique", The Concept of Matter, ed. Ernan McMullin, Notre Dame: University of Notre Dame Press I963, pgs. I5I-I52. Siger's reasons for maintaining the independent status of matter, I will argue, are quite different from the Franciscan emphasis on divine omnipotence.

${ }^{8}$ For the Munich and Vienna reports, see Siger De Brabant: Quaestiones in Metaphysicam. Édition revue de la reportation de Münich. Text inédit de la reportation de Vienne, éd. W. Dunphy, Louvain-la-Neuve: Éditions de l'Institut Supérieur de Philosophie, coll. "Philosophes médiévaux, XXIV" I98I. For the Cambridge and Paris Reports, see Siger De Brabant, Quaestiones in Metaphysicam. Text inédit de la reportation de Cambridge. Édition revue de la reportation de Paris, éd. A. Maurer, Louvain-la-Neuve: Éditions de l'Institut Supérieur de Philosophie, coll. "Philosophes médiévaux, XXV" I983. Hereafter "MM," "MV," "MC," and "MP." The book number will be given in Roman numerals and the chapter number in Arabic (e.g., V.5), followed by the page number from the critical edition. All translations from this text will be my own. 
from form, but instead that between the terms of any formal change-whether it be between complicated substantial forms or basic elementary ones-there remains an underlying material substratum necessary to account for the change itself.

\section{Section I. The Matter as Potency Thesis and Artificial Pro- duction}

In attempting to understand the nature of matter as such, Siger outlines four ways in which matter has been typically understood, and points out the insufficiency of the ways. The four ways are as: privation of form; analogous to the artificial; through form; and through potency to form. ${ }^{9}$ The general problem he identifies with each of the ways is that they always treat matter only in relation to form, united around matter's availability as something formable. Matter is nothing other than the sum total of those forms which it can become. Thus, the four ways of understanding matter are not disparate, but instead share a common association in reference to the functional identity of matter as "the wood-like stuff" underlying all change. Matter appears only as informed, but unlike form itself, matter's incompleteness opens the composite to potential relations to other and contrary forms. In everyday experience, we confront already informed "raw materials," which are deprived of certain forms and yet are able to be transformed into something else. The wood of the forest is currently deprived of the form of stool or paper; through the active agency of an artisan, such wood can be immediately transformed into stools and other furniture or mediately (i.e., through intermediary steps) into paper.

Although Aristotle and most of his scholastic commentators clearly distinguish between natural generation from artificial production, when it comes to thinking the matter of both artificial products and natural substances, the image of matter as a pliable medium corresponding to the active agency of productive action has tended to dominate this metaphysical tradition. Like with artificial products, the matter of natural substances contributes only the stuff to be formed and determined by the activity of the agent (e.g., the father). As, for example, Norbert Luyten states concerning the original metonym of the name "sin" wood):

The original definite 'content', wood, disappears; only the idea of the function of the wood plays in building is maintained and extended to every similar or analogous item. Now, if we ask what

\footnotetext{
${ }^{9}$ MC V.32..., pg. 262.
} 
kind of function is meant here, the general answer seems to be: the function of being that (indeterminate) out of which something can be made. In a more abstract way, we could say: the availability, the plasticity, the determinability which is presupposed to every action of making something. Productive action is conceived as working on a given 'material', which presents a 'possibility' of being shaped in a definite way. Here we seem to have the origin of the conception which sees matter as potency: the given material with its possibility to be shaped, is our matter as potency. Matter appears here primarily as correlative to productive action: that out of which something is made. ${ }^{\text {IO }}$

According to such a model, change is conceived as an agent's productive action of working on an inert and passive material. The passive material is available to be formed because of its nature as pure potency. This means that it is there, but without a determinate nature of its own, it does not restrict or prohibit the imposition or introduction of form. As Luyten clarifies, this functional identity for matter as pure potency correlates with the everyday experience of artificial production, in which an artisan works upon determinable raw materials.

The correlation between the matter of artificial products and matter's metaphysical identity as potency (i.e., as a set of functions), stems from its passive, or purely responsive, role in each case. As that out of which something is comes to be, the being of matter is reduced to a set of functional responses to those agents working upon it. Otherwise, as Aquinas argues, a potency of matter that remains unresponsive to any agent not only would be superfluous, but also non-existent insofar as being follows act and potency is nothing more than that which can be enacted. ${ }^{\text {II }}$ Matter qua functionality thus must be indeterminate and purely passive (patiens tantum) in order to remain responsive to the agent's determination of it. The only limitations on matter's determinability come from its current formal incarnation (e.g., wool resists being determined as saw), whereas if one were to imagine a matter without any form, it would be both indeterminate and purely

\footnotetext{
${ }^{\text {Io }}$ Norbert Luyten: "Matter as Potency...", pgs. I22-I23.

II “ Materia vero prima non est in potentia ad alias formas nisi ad illas quae sunt in rerum natura, vel per principia naturalia educi possunt. Si enim esset aliqua potentia passiva in materia cui non responderet aliqua potentia activa in rerumnatura,illa potentia passiva esset superflua [...]" S. Thomae AQuinatis: Scriptum Super Libros Sententiarum Magistri Petri Lombardi, t.2, ed. P. Mandonnet, Parisiis: P. Lethielleux I929, lib. 2, d. 30, q. 2, a. I, resp. Hereafter "Super Sent."
} 
determinable. ${ }^{\mathrm{I}}{ }^{2}$ Prime matter, thus, is the full spectrum of potencies that can be enacted by agents, a sort of mirror image of all possible formal enactments abstracted from actual concrete hylomorphic unions. ${ }^{\mathrm{I3}}$

In considering together these four ways of understanding matter, Siger thus unearths a deep association between thinking matter as potency and the active processes of artificial production through which matter comes to be variously informed. In both cases, matter at its root can be nothing more than an indeterminate stuff available for determination by some active agent. Matter is the pliable medium to be conquered by form and upon which various forms compete for dominance. If an informed material resists the imposition of another form, for example, if wool resists the introduction of the form saw, such resistance is grounded in the matter's current substantial form, not some inherent resistance on the part of the matter itself. Forms are led into (pro-ducere) or imposed upon a passive medium, which has no nature apart from its spectrum of

${ }^{\text {I2 }}$ See S. Thomae Aquinatis: Quaestiones disputatae, t. 2: Quaestiones disputatae de potential, ed. P. M. Pession. 8 ed. Taurini-Romae: Marietti I949, q. 4, a. I, s.c.. 3: "Praeterea, Deus plus potest operari quam natura. Sed natura facit de ente in potentia ens actu. Ergo Deus potest facere de ente simpliciter ens in potentia; et ita potuit facere materiam sine forma existentem." And ad s.c. 3: Ad tertium dicendum, quod si Deus faceret ens in potentia tantum, minus faceret quam natura, quae facit ens in actu. Actionis enim perfectio magis attenditur secundum terminum ad quem, quam secundum terminum a quo; et tamen hoc ipsum quod dicitur, contradictionem implicat, ut scilicet aliquid fiat quod sit in potentia tantum: quia quod factum est, oporteret esse cum est, ut probatur in VI Phys. Quod autem est tantum in potentia, non simpliciter est."

${ }^{13}$ As Aquinas states: "Materia autem prima non potest praefuisse per seipsam ante omnia corpora formata: cum non sit nisi potentia tantum; omne enim esse in actu est ab aliqua forma. Impossibile est igitur quod ex materia prius a Deo creata aliquis Angelus omnia visibilia corpora formaverit." SCG II.43. See also the following passage from the early text De principiis naturae: "Et sciendum quod licet materia non habeat in sua natura aliquam formam vel privationem, sicut in ratione aeris neque est figuratum neque infiguratum; tamen nunquam denudatur a forma et privatione: quandoque enim est sub una forma, quandoque sub alia. Sed per se nunquam potest esse, quia cum in ratione sua non habeat aliquam formam, non habet esse in actu, cum esse in actu non sit nisi a forma, sed est solum in potentia. Et ideo quicquid est actu, non potest dici materia prima." Sancti Thomae De Aquino: Opera Omnia Iussu Leonis XIII P.M. Edita, t. 43: De principiis naturae ad fratrem Sylvestrum, Roma: Editori di San Tommaso I976, Cap. 2. Matter has neither form nor privation according to its nature, and yet it cannot be stripped of its forms otherwise it would be nothing. Prime matter nothing more than an abstraction in mente of all forms from concrete substances. 
formal enactments, which can only be thought in abstraction from all concrete incarnations. ${ }^{\mathrm{I} 4}$

On such a model of artificial production, Siger in his Physics Commentary draws upon a well-known association between artificial and violent, or extranatural, causation: "artificial generation, such as the building of a home, is not natural... but goes against nature. [...] Those things moving to artificial forms only have a local power of moving as directed by an art, which imposes forms by adjoining and disjoining movements against the nature of the parts." I5 From this passage, we should note how unlike natural causation, artificial causes impose forms external to the medium itself. The matter of such artificial production merely receives the forms without making any contribution of its own. Even if a form conquers its underlying matter, the matter is subjugated without contributing anything to the hylomorphic unity. But to think natural causation as more than the mere imposition of form upon matter, a distinction familiar to Aristotelians, it seems that matter must offer something more than inert availability. $^{\text {I6 }}$

${ }^{\mathrm{I} 4}$ See, for example, Aquinas's rejection of any innate tendencies of prime matter: "Ad secundum dicendum, quod rationes seminales dicuntur materiae inditae, non quia sint intelligendae praeexistere in materia ante adventum formae completae, quasi pertinentes ad essentiam materiae, vel ad rationem ejus, secundum quod est materia; sed per modum quo etiam formae completae in materia esse dicuntur." Super Sent. lib. 2, d. I8, q. I, a. 2, ad 2.

${ }^{15}$ In the Physics, Siger distinguishes between natural causation and artificial causation. "Dicendum quod immo, generation artificialium sicut domus non est naturalis, neque natura formae neque natura materiae, immo contra natura. Nam id quod movetur contra naturam, eius potentia est contra naturam, ut patet in motu gravis sursum ab impellente. Item, moventes ad formas artificialium non habent virtutem nisi localiter movendi quantum est ex arte sua, et quaedam adiungundo, alia segregando inducunt formas, movendo tamen partes contra suam naturam. Non sic est de materia respectu formarum naturalium." See In Physicam II.3 from Siger De Brabant, Écrits de Logique, de Morale et de Physique, ed. Bernardo Bazán, Louvain: Louvain Publications Universitaires I974, pgs. I54-I55. In addition, all references to Compendium De Generatione et Corruptione and Quaestiones Naturales (Lisbonne) will be from this text.

${ }^{16}$ As one witnesses from the following passage, Aquinas seeks to maintain the distinction between natural eduction and artifical imposition without granting matter any activity. "Hoc autem verum non videtur; quia quamvis formae educantur de potentia materiae, illa tamen potentia materiae non est activa, sed passiva tantum [...] Nec tamen sequitur, si in materia est potentia passiva tantum, quod non sit generatio naturalis: quia materia coadjuvat ad generationem non agendo, sed inquantum est habilis ad recipiendum talem actionem: quae etiam habilitas appetitus materiae dicitur, et inchoatio formae. 
As we will come to see, to avoid reducing all change to imposition of form, Siger argues that the agent must act according to a natural propriety as delineated by matter's inchoate dispositions. Whether such inchoate dispositions arise from matter itself, divine implantation, or some other source remains to be seen. But what is clear is that Siger has identified how thinking matter only in terms of passive potency, as the pliable medium upon which change takes place, would reduce all change to extra-natural force. ${ }^{17}$ If unlike artificial production, natural

Non enim eodem modo omnes motus naturales dicuntur, ut in 2 Physic. et in I Cael. et Mund. Commentator dicit, sed quidam propter principium activum intus existens, ut motus localis gravium et levium; et quidam propter principium passivum quod est secundum potentiam ab agente naturali natam in actum educi, ut in generatione et alteratione simplicium corporum: unde et natura dividitur in materiam et formam. Et ideo concedo quod in materia nulla potentia activa est, sed pure passiva; et quod rationes seminales dicuntur virtutes activae completae in natura cum propriis passivis, ut calor et frigus, et forma ignis, et virtus solis, et hujusmodi; et dicuntur seminales non propter esse imperfectum quod habeant, sicut virtus formativa in semine; sed quia rerum individuis primo creatis hujusmodi virtutes collatae sunt, per opera sex dierum, ut ex eis quasi ex quibusdam seminibus producerentur et multiplicarentur res naturales." Super Sent., lib. 2, d. I8, q. I a. 2, resp. But his argument that "matter contributes to natural generation not by acting, but by being disposed to receive action," does not think through the ground of such natural education of forms. He instead relies on the image of God as the cosmic artifacer (see n. 33 below), who, in creating matter along with form, has made available a determinable stuff. What distinguishes "natural eduction" from "artificial imposition" of forms is simply divine decree and no power or nature endemic to matter qua matter. Thus, matter remains a pliable material for production, but now, some acts naturally introduce forms (i.e., as dictated by matter's artifacer), whereas others do so through art.

17 "Tertius modus est secundum quod violentum dicitur necessarium et violentia necessitas: unde dicitur quod necessitas cogit facere aliquid cum aliquid est inferens violentiam. Et declarat quid est violentum sive violentia, dicens quod est praeter impetum et praevoluntatem impediens et prohibens, vim faciens est et vis. Circa quod intelligendum quod, cum duo sint agentia per se, natura et propositum, et omne agens aliquid habet inclinationem ad actionem, illud quod in agentibus naturalibus inclinatio est ad operationem impetus dicitur. Et iterum, impediri dicitur aliquid cum inceperit aliquid et desistat ad incepto, prohiberi autem aliquid dicitur quod non incepit motum vel actionem, cum tamen intendat. Illud igitur quod impedit et prohibet praevoluntatem alicuius, violentiam infert ei; similiter etiam qui impedit et prohibet impetum naturalem, violentans; et hic necessarium dicitur quod fit sic praeter impetum et praevoluntatem, non necessarium simpliciter, sed ex suppositione ut in comparatione ad cogens. Et tunc consequenter ex hoc concludit duo corrollaria. Primum est, quod necessarium sic triste est, et e converso aliquo modo quia quod triste est, contra voluntatem est; tale vero est necessarium, ut dicit SOPHOCLES. Secundum est, quod necessitas non est increpabile aliquid: il- 
causation acts according to the natural inclinations and dispositions of the material parts, without simply imposing a form from without, then we must inquire into the nature of matter qua matter as that to which the active agents must respond.

Thus, despite the deep interconnection between these four ways, Siger argues that none of these ways properly indicates the nature of matter itself. ${ }^{18}$ Although matter must always appear through form, Siger recognizes that matter itself cannot simply be reduced to this functional identity "potency to form." The problem, however, is that only ever appearing in relation to form (i.e., as informed or able to be informed), matter cannot be comprehended directly. As he states in the Munich Report: "Those things, which do not have a form, such a prime matter, [...] are understood only with difficulty."'I9 This is because, as he elsewhere states: "the principle of understanding is form. [...] since matter in its essence does not have any form, through its essence it is not intelligible, though not because it is only the privation of form." 20 Thus, his attempt to indirectly think through the nature of matter qua matter will focus both on dissociating matter from its role as potency to form, as well on questioning the use of the artificial model of production as an image for understanding matter's role in change.

\section{Section 2: 'The Nature of Potency in Siger's}

\section{Metaphysics}

In order to understand Siger's account of matter, we must begin from his discussion of potency. What, if not, pure potency or determinability is the essence of matter? In defining potency, Siger states that commonly speaking, something is said to be in potency when either through one or many agents and media, it able to be transformed into that to which it is in potency. ${ }^{2 \mathrm{I}}$ The child is able to be transformed into an adult, and thus she is said to be in potency

lud enim est vituperabile et increpabile quod fit secundum voluntatem, non tamen ut oportet nec quando oportet nec in quibus etc.; necessitas autem est contrarium motui secundum praevoluntatem, et ideo in eo quod facit ex violentia et necessitate cogente non est increpandus." MM V. Commentum..., pg. 280.

${ }^{18}$ See both MC V.32, pgs. 262-263 and MV V.9..., pgs. 332-333.

I9 "Res igitur quae non habent formam ut materia prima, aut habent formam admixtam privationi ut motus and tempus, de difficili intelliguntur." Appendix I. Fragment de commentaire au Livre II de la Métaphysique..., pg. 4I 8.

${ }^{20}$ MC VII.6..., pg. 335.

${ }^{21}$ MC II.I5-I6. 
to adult. Siger, however, wants to clarify this way of speaking to gain a more refined definition of "being in potency." He maintains that properly speaking, something is said to be in potency to something only when under the proper activity, it is able to go into act. He expounds upon this definition with the following example of a statue. Making a statue is the proper activity of a statue (i.e., sculpting); the element earth (terra) is not able to be actualized (i.e., as statue) under the proper activity of making a statue, but first must be changed into bronze or silver. Thus, Siger argues, earth is not properly said to be in potency to statue, whereas bronze is said to have such potency. He explains this reasoning by further refining his definition. "Passive potency," he states, is the principle of change from another (i.e., an agent). Something in passive potency to a form is capable of actually enacting that form through the agency of another. This agent, we might say, has "active potency" corresponding to the passive potency of the patient. Thus, an agent is called "potent" to the extent that it has power to produce an effect.

Sometimes, Siger argues, matter existing under a certain form is not able to be changed to a contrary form on account of a defect of the agent, that is on account of its impotence (impotentia). In such a case, an agent of greater power (maioris virtutis) is required to enact the change. One flame is not powerful enough to ignite the damp wood, and thus a more powerful source of heat must be introduced. What must be noted, however, is that "impotence" cannot be regarded merely as an agent's inability to produce an effect. ${ }^{22}$ Instead, Siger argues, we must take account of the structured manner of change wherein not just anything whatsoever becomes anything else, but change occurs through a determinate principle. Wine does not come to be from vinegar immediately but requires a gradual series of transformations in order to bring about this effect. Without such an ordered series of changes, he argues, there would be no accounting for how one thing becomes the next because anything could become anything else. Thus, properly speaking, an agent's "inability" to change blood into bread is not an impotence on the part of the agent, nor is blood's resistance to such form a passive impotence. No agent can enact such a transformation,

\footnotetext{
22 "Sed contingit aliquando quod materia ens sub forma non potest transmutari ad formam contrariam propter defectum agentis, sub agente tamen maioris virtutis potest transmutari. Estne haec causa propter quam ex vir non fit puer immediate, et ex sanguine panis? Dico quod non, quia ex nullo agente fit hoc quod ex sanguine fiat panis; ideo, cum sub nullo agente fit transmutation ad talem formam, non est hoc propter defectum agentis. Dico ergo materia existens sub forma sanguinis non est in potentia ad panem nisi secundum quemdam ordinem, et non immediate." MM II. Comm..., pgs. 68-69.
} 
but must act according to the natural order in order to bring about such a gradual change.

In explaining such a claim, Siger states that the true nature of potency can be measured ultimately by the correspondence between prime matter and the Prime Mover. According to such correspondence, every form in potency in prime matter is in act in the Prime Mover, and that which is not in act in the Prime Mover, is not in potency in prime matter. ${ }^{23}$ As the source of pure actuality, those forms at work in the Prime Mover inscribe and delimit a horizon of production for the otherwise unlimited potency of prime matter. This exchange between pure actuality and pure potency enters ordinary experience under the guise of order such that any form whatsoever (quaelibet) cannot be introduced immediately and indifferently into matter, but only those forms proper (propria) to the matter. Matter, instead, has dispositions (dispositionibus) which allow for the immediate eduction or imposition of certain forms (i.e., natural and artificial generation), while resisting others. To what extent such dispositions belong to matter as such, that is, as matter's own contribution to the generative process, remains to be seen.

As has been stated, Siger thus restricts his usage of "potency" to those cases in which one thing can immediately enact or have enacted a certain effect in accordance with "the natural order" of change. Blood cannot immediately become bread, nor can vinegar immediately become wine, and thus properly speaking, vinegar is not in potency to wine, nor blood to bread. Potency, thus, is not the ability to do just anything, but instead the degree of overcoming the necessary counteraction or resistance implicit in all change, which explains why change takes time. What must be noted is that active potency is never a sheer undifferentiated exercise of power (virtus). Even with the pure and undifferentiated concentration of actuality in the Prime Mover (i.e., unmixed with any potency), the expression of an active potency is constituted according to a proper order of change, and thus there can never be an undifferentiated exercise of absolute power. As Siger states: "For whatever is not suited to come to be from whatever indifferently, but everything comes to be from a determinate principle; thus whatever form, to which the matter is in potency, is not imposed indifferently onto matter, but only that form which is proper to the matter." ${ }^{24}$ Siger here seeks to problematize an account of change as mere imposition: matter's potency to

${ }^{23}$ See MM II.I2.

${ }^{24}$ In response to the question "Utrum materia sit in potentia ad formam spermatis," Siger responds: "Dicendum quod non, sed hoc contingit ei ex dispositionibus et forma sub quibus est materia, quia materia existens sub forma sanguinis est propria materia spermatis, non autem panis; actus autem activorum sunt in patiente et disposito: unde 
form cannot be explained merely by an indifferent and forceful imposition of whatever form for upon matter, but instead requires the agent to act according to a determinate principle and as is proper to the matter. ${ }^{25}$

What we can note about matter to this point is that it is not indifferent to the forms introduced by the agent, but there stands a certain "propriety" between matter's determinability and form's determination. ${ }^{26}$ It will not come as a shock to say that certain materials can bear certain forms, whereas other materials cannot. But this does not address whether matter qua matter makes a contribution of its own to change, or whether it merely stands as a blank slate upon which forms are inscribed. In other words, secondary matters can be transformed according to the distinct formal qualities informing them. Thus, the pliability of plastic versus wood can be accounted for by the substantial and accidental forms of each secondary matter. But this says nothing of the matter itself. To invoke Aquinas's martial imagery, matter is the battle-field upon which forms conquer and are conquered; forms may compete with each other, but matter itself has no say in the victor. Whether this is a faithful reading of Aquinas's position cannot be addressed here. However, as discussed above with Luyten, within the thought of Aristotle and the Aristotelian tradition there is a clear exchange between this

quod ex sanguine non fit panis immediate, non est attribuendum defectui agentis. Non enim ex quolibet natum est fieri quodlibet indifferenter, sed unumquodque ex determinato principio; unde non introducitur immediate in materia forma quaelibet indifferenter ad quam materia est in potentia, sed solum illa ad quam materia est propria. Nec hoc est impotentiae agentis attribuendum. Cum enim omnes formae sunt in materia prima in potentia, sint in actu in Motore Primo, quod non est in actu in Motore Primo, non est in potentia in prima materia. Hoc autem non est in actu in Motore Primo ut ex aceto immediate fiat vinum, ordine naturali. Unde solum dicitur aliquid esse in potentia ad aliud, cum sub proprio activo potest transmutari ad illud. Quia ergo sanguis per proprium activum panis non potest transmutari ad formam panis, non debet dici in potentia panis; sicut dicitur in $I X^{\circ}$ quod terra non dicitur proprie in potentia arca, sed lignum." MP II. I I..., pgs. 405-406.

${ }^{25}$ In his Quaestiones Naturales (Lisbonne), Siger asks whether human can be generated directly from the sphere (ex orbe) without a determinate principle (i.e., human). Although he agrees that the sphere is necessary in the case of such generation, there must be an actual human to assist in such generation. See q.4 ..., pgs. I IO-I I I.

26 " [...] si ergo non est actu in Motore Primo ut ex viro fiat puer immediate ordine naturali, ergo nec est potentia in materia immediate, dico" MM II.I2..., pg. 70. Cf. Aquinas's statement on this issue in n. 4 above. 
image of matter as the pliable stuff corresponding to artificial production and its metaphysical identity as passive potency. ${ }^{27}$

What concerns Siger about such a view is that it assumes an artificial model of production for all natural change, thus minimizing, if not discarding, the difference between the natural eduction of forms against their artificial imposition. The importance of stressing the so-called "dispositions" of matter, however, which determine the propriety of form to matter and delineate the "proper activity" (proprio activo) of change, concerns our ability to explain the structure of sublunary change. If all change were thought on the basis of artificial imposition of form, where matter is but a pliable medium without any contribution of its own, we could not account for why each new hylomorphic composite does not simply become identical to its new form or is simply "used up" once the composite is destroyed. Instead, Siger calls upon matter qua matter to explain the fact that each new composite necessarily remains open to new potencies, thus making it impossible for the form simply to conquer the matter, like in the celestial bodies, but also to ensure that with the destruction of each composite, something new will take its place. Change remains continuous. ${ }^{28}$ As we will come to see, matter's remaining the same amidst all change necessitates the continuous structure of sublunary change. But in order to understand this necessity about hylomorphic beings, a new image of matter is required.

Thus, applying the model of natural eduction for both natural generation and artificial production, Siger argues that the actions of agents working both through nature but also through art must respond to inchoate dispositions. He seems to be saying that if we understand artificial production in terms of the artisan's eduction of forms according to the dispositional tendencies of the matter, then this need not be considered violent causation. To illustrate, he provides the familiar example of producing a saw: if the matter of a saw is to be changed

${ }^{27}$ For example, in reference to Metaphysics IX.7, I049aI4-I8, Chris Long argues that by drawing images from the realm of production, Aristotle often conflates natural generation and artificial production. "Aristotle's conflation of natural and technological generation in this passage is particularly unfortunate. It is symptomatic of his continued unwillingness to recognize the active role of matter in natural generation and his tendency to think all generation on the model of production, that is, in terms of hegemony of form." Chris Long: The Ethics of Ontology: Rethinking an Aristotelian Legacy, Albany: State University of New York Press 2004, pg. 97.

${ }^{28}$ See Compendium De Generatione et Corruptione, 3I 8aI4-28..., pg. I32. Siger takes up the question from Aristotle's De Generatione et Corruptione (3I 8aI4-28 and 3I9aI7-22) of why change remains continuous, which—as will be shown — requires matter's power to remain potent. 
to the form of saw under the proper agency of an "active" cause, then, there needs be certain dispositions in the matter, such as durability. Siger goes on to name such dispositions "inchoate forms." 29 These various dispositions enable matter to be much nearer in potency to act, allowing agents to act upon them in various ways. The more disposed matter is to form, the more inchoate the form is, and the more easily transformable the matter is. ${ }^{30}$

Even in regard to First, Siger tends to think of Its agency beyond the usual model as cosmic artificer making the forms to be imposed upon the formless and indeterminate void of matter, what Aquinas calls the "primus factor rerum" to matter's "patiens tantum." 3 I Insofar as matter itself is uncreated and eternal according to Siger, the First does not produce the universe ex nibilo. ${ }^{32}$ It too must draw out those latent dispositions through its abundance of actuality, instead of pre-conceiving ideal archetypes and then imposing them upon a dually created material medium. ${ }^{33}$ In this regard Siger differs from the traditional advocates of inchoate forms insofar as they rely on the divine omnipotence to create such "seminal reasons" along with the creation of matter: God plants the virtual seeds of forms in matter at the time of creation, to be later harvested by the "active agency" of creatures. ${ }^{34}$ For its traditional advocates, such theory affords an undisputed role for divine omnipotence in all change, with creaturely agency serving as an occasion for eduction.

Elsewhere in the Metaphysics, Siger refines his usage of this term "inchoate forms," thinking of them instead as latent tendencies of matter itself to avoid

${ }^{29}$ MC V.I6..., pgs. 222-223.

${ }^{30}$ MP V.6..., pgs. 438-440.

${ }^{3 \mathrm{I}}$ See n. 4 above.

32 "Formae enim procedunt ex orbe sicut ex causa generante; materia autem, cum sit ingenita, non sic; sed ad esse orbis sequitur esse materiae, sicut ad esse Causae primae sequitur esse sui effectus immediati. Et ex hoc apparet quod orbis quantum ad idem non est causa materiae et formarum materialium. Cum enim sit causa generans respectu formarum materialium, per id quod novum est in eo causa est earum; et ideo accidit continue novitas in formis materialibus. Per id autem quod aeternum est in eo, ut per substantiam suam, est causa materiae, quae secundum substantiam aeterna est." MC V.I I, pg. 209.

33 This is the image that Aquinas, inter alia, tends to favor. "Respondeo dicendum, quod emanatio creaturarum a Deo est sicut exitus artificiatorum ab artifice; unde sicut $\mathrm{ab}$ arte artificis effluunt formae artificiales in materia, ita etiam ab ideis in mente divina existentibus fluunt omnes formae et virtutes naturales." Super Sent., lib. 2, d. I8, q. I a. 2, resp.

34 See Frederick Copleston: A History of Philosophy. Volume II: Medieval Philosophy From Augustine to Duns Scotus, New York: Doubleday I950, pgs. 9I-93. 
thinking of them as forms-in-waiting. He argues that if inchoate forms are thought to be lesser grades of the educable form, meant to explain matter's receptability to the form, then we would need an account of how they came to be in matter. Instead, he states: "nothing is eternal in matter except its substance." 35 Thus, he rejects the view that such dispositions can be thought of as lesser grades of the educable form. If semen possessed as lesser grade of the form human, there would need to be an explanation of that diminutive grade of the form. Instead, he argues, the dispositions themselves are called upon to explain why matter can receive such forms at all. Matter's inchoate disposition must account for its fundamental susceptibility to form and yet cannot call upon lesser grades of such forms to carry the explanatory burden..$^{36}$ Thus, Siger argues, the forms only "preexist" according to matter, and not as lesser grades of the forms themselves.

Although there is no formal preexistence in matter prior to the eduction of the actual form, Siger recognizes that something must account for matter's receptivity to form. Otherwise, we are left with the same problem addressed above of thinking of all causation in terms of forceful imposition. Thus he states: "Forms therefore preexist before generation only according to matter and not according to some grade of themselves." ${ }^{37}$ Such preexistence according to matter accounts for what we might call matter's inchoate susceptibility to form, which enables it to continually bear or take on forms without merely having form imposed upon it by an external agent. Although Siger simply names such material preexistence "potency," we will need to be careful in understanding what he means by this term and how it relates to matter itself.

His use of "potency" in this context cannot be thought simply in terms of "not-yet-enacted form," otherwise we attempt to explain the generation of form in matter in terms of "relation to form," presupposing the very notion needing to be explained. Instead, matter's contribution runs deeper. Matter is capable of a multitude of contrary potencies (i.e., relations to form), and even as certain of these potencies are actualized, the new composite-in cases of generation-stands in potency to new forms on account of its matter. The ore that becomes iron is no longer in potency to the form of iron, but acquires new potencies. But, and this is Siger's point, we cannot explain this continuous susceptibility of matter to form in terms of the form themselves or possible relations to form. These change and allow contrariety. Thus, if we adopt the

\footnotetext{
${ }^{35}$ MC VII.I $5 \ldots$, pg. 354.

${ }^{36} \mathrm{Ibid}$.

${ }^{37}$ Ibid.
} 
artificial model of imposition, at best we can state that each new composite just happens to be potent to new forms, but there can be no explanation of why each newly generated hylomorphic composite necessarily is not conquered by its form, like the forms of ethereal matter, or is altogether used up with the corruption of the compound, but instead remains potent. There is no reason why the form cannot completely conquer its matter, except for the accidental fact that another form might compete with it. But to establish a more fundamental point about sublunary change itself, namely that all hylomorphic unities continue to remain potent, Siger must rely upon a more fundamental explanation concerning matter itself.

The philosophical danger of granting matter its own power or nature beyond the intelligible actuality of form is that Siger risks fragmenting the hylomorphic unity of each substance and transforming the underlying substrate into a type of Lockean "I know not what." Or worse, his explanatory apparatus seems to echo: "From the indeterminacy of primordial chaos, first comes Gaia and then later other immortal gods appear," a mythical theogany whose originary first principle lies beyond the scope of intelligibility. One way of circumventing this problem, and avoiding the embarrassing conclusion that an unknowable prime matter contributes to its determinability, is simply to reject the existence of prime matter altogether. William Charlton, for example, arguing for an elimination of this material remainder, has stated: "[...] there will be no empirically discoverable difference between a world which contains prime matter and a world such as [Hugh R.] King and I wish to impute to Aristotle, in which there is nothing more basic that [sic] the elements, and they change into one another without there being anything that remains." ${ }^{8}$ But, as we will come to see, Siger makes the opposite bid. He insists that not only can prime matter not be reduced to potency, but also to account for the nature of change, we must grant to matter a minimal "reality" — a term to which I will return—distinct from its actuality in relation to form.

\section{Section 3. On Matter's Relation to Potency}

In all four Reports his Metaphysics, the issue of matter arises upon the heels of this discussion of potency. ${ }^{39}$ The differences between the Reports, although

${ }^{38}$ William Charlton: "Prime Matter: a Rejoinder", Phronesis XXVIII-2 (I983), pg. I97. For King's position, see above pg. 24 and n. 78 below.

39 In the Cambridge Report, he states: "Et dico quod ex materia prima fit aliquid sicut ex eo quod est medium inter non esse simpliciter et esse in actu. Ipsa enim est ens 
not radical, are worth mentioning. The first is the nature of the question itself. Whereas the Munich Report asks whether matter is a cause of the thing, the Cambridge and Paris Reports ask whether prime matter can be an account (ratio) of causing. Furthermore, the Vienna Report does not ask whether matter is a cause, but asks whether potency is the essence of matter, a question implicit in all of the rest. The Reports seem consistent in their basic argumentative structure, although the probing of prime matter gives rise to a different example, as will be seen shortly. In all cases, Siger argues that matter is a cause and that the account of its causing is because from it something comes to be and it remains in the thing. Thus, as a principle of generation, matter retains an abiding influence on the actual "completed effect" (factum) of both artificial production and natural generation. In response to this similar question in all four Reports, Siger argues that the essence of matter qua matter cannot be potency, at least not in the usual sense in which potency is understood as relation to form..$^{40}$

Based on an argument from Aristotle's Physics concerning motion, ${ }^{4 \mathrm{I}}$ the basic structure of Siger's argument for this non-identity from all four Reports of his Metaphysics is the following: If matter qua matter and matter qua potential X were the same, then potency to $\mathrm{X}$ and the potency to not- $\mathrm{X}$ also would be the same because a numerically identical matter subtends both potencies. Matter qua $\mathrm{X}$ and matter qua not-X are identical as matter qua matter, and therefore matter qua matter must be distinct from each of these contradictory potencies. Otherwise, the potency to $\mathrm{X}$ and the potency to not-X, along with their concomitant acts (i.e., $\mathrm{X}$ and not-X) also would be the same. Therefore, matter qua matter and

in potentia tantum. Ens autem in potentia nec est simpliciter non ens nec ens in actu, sed est medium per abnegationem inter ista. Ad rationem dicitur quod privatio est non ens per se. Materia autem solum est non ens per privationem admixtam substantiae suae. Cum autem ex materia prima fit aliquid, quamvis in facto esse maneat secundum substantiam, corrumpitur et aliquo modo manet; sicut cum ex puero fit vir, etsi corrumpatur secundum aliquod accidens eius, manet secundum substantiam suam.” MC II.I6..., pg. 62.

${ }^{40}$ See MP VII.3 and n. 39 above. Here he says that such ens in potentia is an intermediary through refusal (abnegationem) between non-being and being in act.

${ }^{4 \mathrm{I}}$ Aristotle, Physics III.I. All references to Aristotle will be from Aristotle: The Collected Works of Aristotle, ed. Jonathan Barnes, 2 vols. Princeton: Princeton University Press I984. The first thing to note is the argument to which Siger refers. He references the wellknown passage from Physics III.I in which Aristotle defines motion. Whereas Aristotle's concern is to understand motion, and only introduces secondary matter in order to get at the latter's moveability, Siger uses this argument as if it were a discussion of matter and potency without so much as mentioning the issue of motion. 
matter qua potential $\mathrm{X}$ are not the same. Thus, to distinguish contrary actualities (e.g., health and sickness, statue and not-statue) and allow each to persist in its self-identity and to remain distinct from its opposite, matter itself must be nonidentical to either of the (preceding) contrary potencies. Bronze qua bronze, for example, must be distinct from either "potential statue" or "potential chalice." Having extracted this unified structural basis of the various arguments, we now can present the arguments as they appear in each Report.

In the Munich Report, Siger introduces the example of a statue, using bronze as the artistic medium. The argument focuses on the account (ratio) of matter as a cause. Siger argues that since bronze is bronze and (bronze is) potential statue, the account of bronze qua bronze is different than the account of bronze qua potential statue. He substantiates this claim with the following argument, adding the example of blood in sickness and in health into the mix. ${ }^{42}$ He states: since, if the account of bronze qua bronze and bronze qua potential statue were a single account, or likewise the account of blood qua blood and blood qua potency to health, in that same account (i.e., the single account of the matter and its potency to $\mathrm{X}$ ), at the same time there would be an account of bronze qua bronze and bronze qua potency to not-statue; or blood qua blood and blood qua potency to sickness. If this were the case, then there would be only a single account of the capacity to be statue (or healthy) and the capacity to be not-statue (or sick). Furthermore because potencies are of the same account in the same way with their acts, that is, they are defined in relation to formal enactment, statue and not-statue, or health and sickness, (i.e., the acts) also would be the same. This is impossible because any account, which at the very least cannot distinguish between contradictories (e.g., statue and not-statue) or contraries (e.g., health and sickness) but instead unifies them as one and the same, offers no account at all.

42 "Quod autem materia non sit essentialiter in potentia, manifeste apparet ex dicto ARISTOTELIS $I I I^{\circ}$ Physicorum: dicit enim quod, cum aes sit aes et in potentia statua, alia est ratio aeris secundum quod aes et secundum quod in potentia statua. Et probat hoc sic: quoniam, si ratio aeris secundum quod aes et secundum quod potentia statua sit ratio una, et similiter ratio sanguinis secundum secundum quod sanguis et secundum quod in potentia ad sanitatem, eadem ratione erit eadem ratio aeris secundum quod aes et secundum quod in potentia ad non statuam; et sanguinis secundum quod sanguis et secundum quod in potentia infirmus; et si sic, tunc posse sanari et posse infirmari sunt unum ratione; quare et sanitas et infirmitas unum sunt ratione, quia potentiae sunt eiusdem rationis aliquo modo cum actibus; hoc autem est impossibile; quare impossibile est primum.” MM V.5 .., pg. 248. 
Before granting a stamp of approval to this argument, we must examine one of the premises and ask why should we accept the at the same time clause? This premise stated that within a single account (i.e., of the matter and its potency to $\mathrm{X}$ ) a second account (i.e., of the matter and its potency to not-X) must also be included at the same time. The reason, which we will see more clearly argued in the Vienna Report below, is as follows: an account of matter must include all potencies of which it is capable, or we might add in reference to the early discussion, which are "proper" to it. ${ }^{43}$ Thus, an account of blood, for example, includes potency to health and also includes potency to sickness, or "not-health." An account of prime matter, likewise, includes potency to the elementary contraries of hot/cold and moist/dry, and thereby to the four elements water, earth, air, and fire. No one has a problem granting this claim that blood is in potency to contraries (i.e., both health and sickness), or that prime matter is in potency to water, earth, air, and fire. The problem arises, however, only if we numerically identify blood with such contrary potencies. Such an identification would require an account of blood's essence, or the substance through which it stands in potency to various forms, to be the same as those potencies, and thus the same as "health and sickness," which entails a contradiction.

The examples of bronze and blood obviously concern secondary matter, as opposed to prime matter. With the Cambridge and Paris Reports, Siger treats the latter. The Cambridge Report takes up the question of whether prime matter offers a causal account. ${ }^{44}$ Here the focus shifts to a more subterranean level, that of prime matter standing in passive potency to the four elements of earth, water, air, and fire. Every other sublunary body is composed of some proportion of these elemental building blocks, together whose combination give rise to more and more complex matters (e.g., blood and bronze) able stand in potency to increasingly complex forms (e.g., bodily health and statues). Bronze, for example, can be broken down into copper and tin, which can be further broken down and distinguished according to their ratio of the four elements. Once reaching this elementary level, the underlying issue thus concerns whether prime matter

\footnotetext{
${ }^{43}$ See MV V.9..., pg. 332.

44 "Quia igitur per ARISTOTELEM hic, ratio causandi ipsius materiae est quod sit illud ex quo fit res cum insit, ideo iuxta hoc quaeritur utrum materia prima possit esse ratio causae hoc modo causalitatis. Et quod non videtur, quia per ARISTOTELEM et COMMENTATOREM, ex non ente penitus non potest fieri ens, quia ipsum simul esset ens et non ens. Similiter in proposito, cum materia sit essentialiter in potentia ad ea quae sunt ex materia, si ex ipsa fieret aliquid in existente, ipsum simul esset in actu et in potentia, quod est inconveniens." MC V.5 .., pgs. I98-I99.
} 
can be identified with its potency to these basic elemental formations and their combination of contraries (i.e., hot/cold, moist/dry).

The main argument for this non-identity begins again with the example of a statue. To recite the basic argument from above, before unpacking its details in terms of prime matter below, Siger argues that bronze qua bronze remains the same both when it is statue and when not-statue, thus if bronze itself were identical to bronze qua potential statue, the capacity to be statue and the capacity to be not-statue would be the same, as each would be identical to the bronze qua bronze. ${ }^{45}$ We should note the addition of the clause that does not appear in the Munich Report: "since bronze qua bronze remains the same when it is a statue and when it is not-statue" (e.g., when it is statue and when it is chalice or Olympic medal). The significance of including this clause, which will also appear with the example of prime matter, is to show that since matter remains the same under two contrary forms, its identity to either potency and its corresponding actuality would require each contrary's identity with the another, under which matter is the same matter. Instead, bronze qua statue and bronze qua chalice (i.e., not-statue) are identical, but only qua bronze. Matter, in this case bronze, as that which grounds such distinct actualities and their corresponding potencies, must itself be non-identical to either of the contrary potencies or their eventual actualization. To enable such contrariety, either in potency or in act, matter itself must be something more than a standing reserve for the enactment of contrary potencies for reasons that will becomes clear in what follows.

Using the example of earth (prime matter qua dry/cold) and fire (prime matter qua dry/hot), Siger then translates the statue-argument into similar terms for prime matter. He argues that if prime matter itself were essentially its potency to the form of earth and its potency to the form of fire, since its essence is the same under the form of earth and the form of fire (i.e., in both cases it is prime matter), then the capacity to be earth and the capacity to be fire would

45 "Ad rationem in oppositum intelligendum quod non oportet id quod fit ex materia prima simul esse in potentia et in actu secundum quod potentia distinguitur contra actum, quia potentia corrumpitur apud adventum actus. Et ex hoc sequitur quod potentia non est essentialis materia, quod potest probari ratione. Arguit enim ARISTOTELES III Physicorum quod non est idem aes secundum quod aes et secundum quod potentia statua, quoniam si sic, cum maneat idem aes secundum quod aes cum est statua et cum est non-statua, ergo idem esse posse esse statuam et posse esse non-statuam. Similiter arguam de materia prima. Si enim ipsa essentialiter esset potentia ad formam terrae et ad formam ignis, cum essentia sua sit eadem sub forma terrae et ignis, posse esse terram et posse esse ignem essent idem, et tunc terra et ignis essent idem, quoniam potentiae non distinguuntur nisi ex actibus." MC V.5 .., pg. I99. 
be the same, and earth and fire would be the same and indistinguishable. Thus, prime matter must be non-identical to its potency to earth, otherwise a numerical identity between the two would require either that prime matter has only this single potency (i.e., to earth) or that its multiple potencies (i.e., to air, water, earth, and fire) are identical and indistinguishable from one another. For there to be a manifold of distinct and contrary potencies along with their corresponding enactments, matter itself must remain non-identical and indifferent to this composite series otherwise its own identity would consume their distinction.

The move to essentially distinguish matter and potency may be too quick. True, matter cannot essentially be contrary potencies (e.g., hot/cold), just as Socrates cannot essentially be, for example, able to sit and able to stand. But just as Socrates is a potency to contraries without being contrary potencies, so too could not prime matter be a pure potency to such contraries without being such contraries? ${ }^{46}$ With Socrates, we might say that while reclined he can sit or he can stand, that is, at the same time, Socrates is a potency to contraries. And yet Socrates's underlying identity as the subject of such contrary potencies does not render them identical. Likewise, prime matter can become earth or fire (i.e., it stands in potency to such forms) and yet of itself, it has no identity apart from its current actual form and the forms it can become. In short, must "prime matter" and "potency to elemental contrariety" be essentially non-identical? To answer this question, we must turn to the other two Reports.

In the much pithier presentation of this argument in the Paris Report, Siger states that an account of blood qua blood and an account of blood qua health and sickness are distinct, otherwise the capacity to be healthy and the capacity to be sick would be the same. ${ }^{47}$ And yet to reissue our question, does Siger mean to say only that an account of blood qua blood must be distinct from either of the contrary potencies (i.e., qua health or qua sickness), or also that it must be distinct from its potency to contraries (i.e., potency to health and to sickness)? Compare this to his argument in terms of prime matter, which immediately follows:

${ }^{46}$ I am grateful to Professors Susan Brower-Toland and Colleen McCluskey of Saint Louis University for directing me to this distinction.

47 "Nec sequitur, si materia non est ens in actu essentialiter, quod sit ens in potentia essentialiter, licet ens per actum et potentiam dividatur. Nam eo quod materia non est cognoscibilis per suam essentiam, ideo utimur ad eius cognitionem habendam potentia loco differentiae essentialis. Sicut enim dicit ARISTOTELES $I I I^{\circ}$ Physicorum, alia est ratio sanguinis secundum quod sanguis et secundum quod potentia sanum vel infirmum, aut idem esse posse sanari et posse infirmari. Similiter, si non esse alia ratio materiae secundum quod materia et secundum quod in potentia aqua, idem esset posse esse aquam et posse esse ignem.” MP V.I..., pg. 433. 
an account of prime matter qua prime matter must be distinct from an account of prime matter qua water, otherwise the capacity to be water (i.e., moist and cold) and the capacity to be fire (i.e., dry and hot) would be the same. The latter leaves out "and fire," which would seem to follow "prime matter qua water" thus paralleling the first argument's "blood qua health and sickness." Reading the argument in this way suggests that Siger is only really arguing that blood qua blood must be distinct from blood qua potency to health and it must be distinct from blood qua potency to sickness, but it need not necessarily be distinct from blood qua potency to health or to sickness. Thus, blood, and more fundamentally prime matter, is essentially constituted as being potency to contraries without being contrary potencies. This argument in terms of prime matter, like the arguments from the Munich and Cambridge Reports, seeks to distinguish (prime) matter from its being contrary potencies, but not necessarily from its potency to contraries. With the Vienna Report, however, we find the clearest expression of this argument and an answer to our question.

In this Report, he presents another variation on this basic argument against the identification of matter with potency. ${ }^{48}$ Bringing together the essence of the arguments from the other Reports, Siger maintains that since the substance of matter in potency to every form is numerically one, if potency were its substance, then matter through numerically one and the same potency would be in potency to every form and to every contrary form. Thus, because the substance of matter in potency to contrary forms is one, if potency were matter's substance, then

${ }^{48}$ Following Averroes, he states that matter is not essentially potency because the essence of matter is numbered among the absolute things, whereas potency is among those things said of something (dictorum). This seems to correspond to a distinction in Averroes, as McAleer makes clear. Concerning Siger, he states: "His discussions of matter center on Averroes' distinction that prime matter is not to be identified with potentiality. Obviously, in divorcing potentiality from prime matter questions (quite foreign to Thomas) arise as to the metaphysical status of each and their relationship to one another. Like most Latin commentators who accepted Averroes' distinction, Siger was left to discern quite what Averroes' meant by distinguishing matter and potentiality. Siger understands Averroes to say that there is a first passive potency (potentia passiva prima) that is the same as the substance of prime matter and quite different kind of passive potency which is distinct from prime matter. This second potency is not to be identified with the substance of matter but is a relation (potentia ad aliquid dicitur, materia non). Siger describes potency as something added (ratio potentiae videtur esse addita) [No italics in original] to the substantial being of matter and so an accident to its substance (potentia est accidens substantiae materiae)." Graham J. McAleer: "Who were the Averroists of the Thirteenth Century?: Siger of Brabant and Neo-Augustinians in Respect of the Plurality Controversy", Modern Schoolman LXXVI-4 (May 99), pg. 283. 
the potency to contrary forms (e.g., to sit and to stand, to be hot and to be cold) would be numerically identical. Since the essence of matter is one, anything identical to the essence (i.e., its various and contrary potencies) also must be one, and thus contrary potencies would become indistinguishable. ${ }^{49}$ Furthermore, Siger argues if the substance of matter which is in potency to every form were one, it would follow that the potency of matter to every form is one. But since each potency is potency to a single form (cum una potentia non sit nisi ad unam formam), it would follow that either matter would have to be but potency to a single form, or that each form to which matter is in potency would be one and the same form. From this Siger concludes that matter is not substantially its potency.

To sufficiently differentiate the multiplicity of forms receivable by prime matter, and to hold them apart in their difference, matter itself (i.e., matter qua matter) must remain non-identical to the multitude of potencies that if funds. Otherwise, its numerical identity to potency would collapse- or better "absolve"-potency's manifoldness into an undifferentiated union of identity. Each passive potency corresponds to the enactment of one formal actuality (e.g., statue, but not chalice), since potencies are indistinguishable unless according to their enactment (potentiae non distingumntur nisi ex actibus), defined by its relation to subsequent enactment. If matter itself were defined merely as such a spectrum of potencies, it would itself be in the category of relation. Although its identity as relation would be multiple, the underlying identity between these changing relations amidst the flux of change would be fractured, at best a per accidens abstract heap of relations without per se continuity.

As the Vienna Report has shown, because potency in respect to act is potency to a single form, matter itself must remain both open to and other than any potency or potencies. To confuse matter with potency thus understood

49 "Unde et hoc etiam ostendit quaedam ratio quam consuevi facere ad hoc. Cum enim una numero sit substantia materiae quae est in potentia ad omnem formam, si potentia esset sub substantia, sequeretur quod materia per unam et eandem potentiam numero esset in potentia ad omnem formam <et $>$ ad formas contrarias; quia, sicut substantia materiae quae est in potentia ad contrarias formas est una, sic, si potentia sua esset sua substantia, una numero esset potentia ad contrarias formas." And further: "Immo plus, sequeretur quod dicit ARISTOTELES XII Metaphysicae. Quia, si potentia materiae esset idem cum substantia materiae, cum substantia eius quae est in potentia ad omnem formam sit una, sequeretur quod potentia materiae ad omnes formas esset una. Sed cum una potentia non sit nisi ad unam formam, sequeretur quod materia non esset potentia nisi ad unam formam, aut quod omnis forma ad quam materia est in potentia esset una forma. Materia igitur substantialiter non est sua potentia.” MV V.9..., pg. 332. 
has been the mistake of the artificial production whereby matter is treated as "the wood-like stuff" with no identity apart from each of its multiple potencies. Instead, by calling this model into question, Siger has shown that since prime matter, which is in potency to every elementary form (i.e., earth, air, water, and fire), is one, if potency were its substance, it would follow that matter would be in potency to every form and to contrary forms through numerically (numero) one and the same potency. ${ }^{50}$ This is because, just as the substance of matter, which is in potency to contrary forms, is one, in this way-if its potency were its substance-potency would be numerically identical (una numero) to contrary forms. Matter can be a potency to contraries without being contrary potencies because of its non-identity to its multiple and distinct potencies. It must have a multitude of distinct potencies, distinct from one another and from matter itself as the ground of their multiplicity. Prime matter is in fact in potency to the contrary tactile qualities of hot/cold and moist/dry, and thereby to the elements, but such a description does not exhaust the substance of matter qua matter. From this, Siger concludes that matter is not substantially its potency.

\section{Section 4: Matter beyond the Act/Potency Divide}

The problem with not using potency to identify matter would be either that matter must have actuality — since it is not pure potency-or that it must be something beyond act and potency. Since form imparts actuality in an Aristotelian universe, non-formal actuality seems spurious. Likewise, to speak of something beyond act and potency would incur the cost of obscurantism. The traditional argument against affording prime matter with extra-formal reality-I hesitate to use "actuality" for reasons addressed below-would be that it would reduce all change to a form of accidental change of an underlying and unchanging substratum. Thus, the change between water and air would not be a substantial change because the substratum itself-having been afforded some reality-remains unchanged. Its elemental transformations are but an accidental modification, thus nullifying the difference between substantial and accidental change.

What we find with Siger, however, is an attempt to dissociate the reality of prime matter from its actuality. Although he struggles for the language to

${ }^{50}$ In addition to MV V.9, see also the following from Siger's Physics, where he references the argument from Aristotle's Physics: “[...] tertio Physicorum dicitur quod posse sanari et posse infirmari alterum est ratione, quia si non, idem esset sanitas et infirmitas; ergo potentia materiae non est una < quia> ad contraria." Physics I.I..., pg. I49. Matter, which is one, cannot be potency because potency is to contraries. 
express such a distinction, and most often fumbles around with awkward expressions, he nevertheless seizes upon a metaphysical demand whereby prime matter enjoys an irreducible ontological reality. ${ }^{5 \mathrm{I}}$ Based on Siger's arguments to grant a non-formal reality to the matter of hylomorphic substances, Graham McAleer has argued that Siger's view entails a plurality thesis, albeit not a plurality of forms, but a plurality of things (res). This means that each hylomorphic composite is a unity of multiple "realities," one of which is of matter. As McAleer argues:

Underlying Siger's plurality thesis is the principle that being (ens) and thing (res) have a greater metaphysical extension than the act of being (actus entis). With this principle, Siger rejects the Thomistic identification of being with act: while it might be true that matter cannot be in act without form it does not follow from this, for Siger, that the essence of matter is not some manner of being (and thing) independently of act and form. ${ }^{52}$

Such an independent manner of being (modus essendi) would be matter's substanding, or subtending, the process of change, remaining amidst even the most radical change. It would have an irreducible reality, even if not actuality. To avoid obscurantism, Siger must show why prime matter has a reality irreducible to the actuality brought by form. The burden thus becomes to show why according to the very process of explaining the world of hylomorphic substances, we are left with an irreducible material remainder neither knowable per se and yet indispensable in rendering essential accounts. ${ }^{53}$

${ }^{5}$ See, for example, the following identification of matter with substance: "Materia igitur, cum sit ens, sit substantia. Ad rationem in contrarium, cum dicis $<<$ illud cuius esse est posse esse non est substantia $>>$, verum est cuius esse substantialiter est posse esse. Sed cum dicis $<<$ materiae esse est posse esse $>>$, verum est, sed non esse substantiale, sed accidentale, est sibi, scilicet posse esse, ut alias ostensum est. Ideo non oportet quod materia non sit substantia." MV VII.6..., pg. 395. Below we will discuss the essence of matter. I would maintain that Siger might substitute the term "reality" and maintain the same results.

${ }^{2}$ McAleer, "Who Were the Averroists?...”, pg. 288.

53 The term "remainder" comes from Theodor Adorno's Negative Dialectics. He states: "The name dialectics says no more, to begin with, than that objects do not go into their concepts without leaving a remainder, that they come to contradict the traditional norm of adequacy." Theodor W. Adorno: Negative Dialectics, trans. E.B. Ashton, New York: Continuum I973, pg. 5 . 
As Siger argues in the Paris Report and elsewhere, the division of being into act and potency does not suffice to capture the essence of matter. Although matter is subjugated through capacity (subiecaturperposse), this is not the essence of matter. ${ }^{54}$ He states that: "because matter is not knowable through its essence, we use potency in the place of an essential difference in order to know it." 55 Potency functions like a differentia, which allows us to apprehend matter without actually seizing upon its true nature. This means that potency does not constitute the essence of matter as the disjunctive attribute or differentia of being whereby matter would be "ens in potentia" to form's "ens in actu." Such a differentia-like function for potency only arises through a comparison between matter and form, treating matter as it relates to form, but not as a real definition. ${ }^{56}$

Although in rerum natura, matter is never found without form according to Siger, this does not entail that "orderable to form" comprises the being of matter. ${ }^{57}$ Such an identity would mean that prime matter is nothing more than yet-to-be-enacted potencies, or a set of relations. Although matter qua matter is enacted in relation to form, matter itself is essentially distinct from its relations to form. Siger thus states: "It should be said that material form is not the cause of matter qua essence [...] but only the cause of matter qua act." ${ }^{8}$ In terms of prime matter, the elements are generated from the circulation of the celestial sphere. Thus, the activity of this celestial agent is the cause of the generation of new elemental forms in prime matter. But it is not the cause of prime matter itself, which Siger argues is ungenerated and eternal according to its essence. ${ }^{59}$

${ }^{54} \mathrm{MM} \mathrm{V.5.}$

55 "Nam eo quod materia non est cognoscibilis per suam essentiam, ideo utimur ad eius cognitionem habendam potentia loco differentiae essentialis.” MP V.I ..., pg. 433.

${ }^{56} \mathrm{MC}$ VII.5 and MV VII.6.

57 "Et si dicitur quod materia essentialiter est in actu vel in potentia, sed non est essentialiter in potentia, quare potentia est essentialis materiae, intelligendum, sicut dicit AVERROES libro De substantia orbis, quod, si materia esset potentia seu posse per essentiam suam, cum posse intelligatur respectu formae, materia per essentiam suam non esset de numero eorum quae habent esse absolutum, sed eorum quae babent esse in ordine ad aliud, et tunc non esset substantia [m.e.]; hoc autem est impossibile; quare potentia non est de essentia materiae." MM V.5 .., pg. 247. As this argument clearly states, if matter were not among those things having being absolutely, then it would not be a substance, and this is impossible. This means that matter cannot be understood with respect to form, because then it would be counted among things ordered to another. Thus, even though matter cannot be reduced to formal actuality, it is still counted among esse absolutum and substances.

58 "Dicendum quod forma materialis non est causa materiae quantum ad essentiam...sed verum est quod est causa ut materia sit in actu [...]" MM V.Io..., pg. 254.

${ }^{59}$ See MC V.II..., pg. 209 and n. 32 above. 
Nor is Siger willing to say that prime matter is nothing other than the series of various forms enacted by the sphere. The reason, as discussed above, is because the mere imposition of forms without a material disposition fails to explain why matter necessarily remains potent without either becoming identical to any single form or simply being used up. Even though celestial motion is eternal and unceasing, if matter by its nature did not remain potent, the continual imposition of forms would not only make all sublunary causation violent, but also fail to explain the necessity of matter's untiring power to be informed without being used up over time or completely conquered by any single form.

For this reason, Siger describes the material remainder as "that which sustains the change" (quod sustineat illam transmutationem) and upon relinquishing one form, it "wades under" or "subtends" its opposite (vadat sub alia). ${ }^{60}$ If the elements themselves were called-upon as the basic units of reality, then non-being would change into being: cold, or the not-being of hot, would per se change into hot. As Aristotle states in On Generation and Corruption, for the elements to act upon and be affected by each other, however, they must share a common, yet inseparable, substratum by which such change transpires. ${ }^{61}$ For there to be a contrariety of basic and disjunctive tangible qualities-i.e., the active qualities of hot/cold, and the passive qualities of dry/moist, which compose the elements - there must be something distinct from the terms of change. As Siger concludes: "Therefore matter which is the subject of generation in a substance is something distinct from its form and privations of forms." ${ }^{12}$ The original privation cannot be that from which something comes to be, otherwise a non-

60 "Quod etiam generatio requirat suiectum quod transmutetur de uno ad aliud patet etiam, quoniam unum oppositum per se non transmutatur ad aliud oppositum, quia sic non ens per se fieret et esset ens, quod est impossibile. Non ens enim, sicut non potest esse ens, sic nec per se transmutari ad esse vel ens. Ergo oportet quod sit suiectum aliquod quod sustineat illam transmutationem, quod scilicet relinquens unam formam oppositam, vadat sub alia. Hoc autem suiectem est materia. Materia ergo est aliquid distinctum ab opposito, id est a privatione, ut iam visum est, ita quod materia est aliqua natura distincta a privatione.” MV VII.5 ..., pgs. 393-394.

${ }^{6 I}$ ARistotle: De generatione et corruption, II. I, 329a29-32.

62 "Dico ad hoc quod omnis generatio eget subiecto et eget opposito: opposito quidem quia non fieret aliquid <album $>$ si esset album; subiecto autem quia aliter non esset aliquid quod transmutaretur. Oppositum autem, cuius est privatio, non recipit esse; ex quo apparet quod materia distincta est a privatione. Item, differt generatio substantiae a generatione in aliis entibus. Quod enim transmutatur secundum substantiam, non retinet nomen et definitionem; quod tamen transmutatur secundum alia entia, retinet. Nomen autem et definitio a forma est. Et ideo termini generationis in substantia sunt formae et privationes formarum. Subiectum autem transmutationis universaliter distinctum est 
being per se would change into a being. Thus, amidst the relinquishing of forms, something non-identical to any given form must sustain the change. This nonidentical "something," which is the subject of change and distinct from both privation and its opposite, is matter (materia). This is why, when discussing the elements and prime matter in his Commentary on the Physics, Siger states: "For although fire is generated from air and nothing sensible remains, matter, however, remains." ${ }^{63}$ The elements change, but matter must remain. ${ }^{64}$

In the Vienna Report, Siger further asks whether matter is some being (aliquod ens). Here we should assume following McAleer, being has a larger extension for Siger than act. In response, he argues that an account of generation shows that matter must be some being. This can be seen by looking at the commonality in all manners of change such that some underlying subject is necessary to sustain the change. Even the radicality of substantial change must be subtended by continuity of this underlying subject. Without such a subject, we would say "there was Socrates, now there is a corpse," but such an account would lack any sort of continuity between these disparate moments and the new thing would appear ex nibilo in place of the old. ${ }^{65}$ Instead, Siger calls upon mat-

$\mathrm{ab}$ utroque terminorum. Materia igitur quae est subiectum generationis in substantia est aliquid distinctum et a forma et a privationibus formarum. Non tantum igitur est materia privationes formarum entium, nec secundum se est aliquid entium, sed est aliquid cui accidunt tam entia quam privationes.” MC VII.6..., pgs. 334-335.

63 "Quamvis enim ignis generetur ex aere et nihil sensibile manet, tamen materia manet." Physics II.20..., pg. I8I.

${ }^{64}$ In terms of the question "Utrum prius adveniat materiae aut forma substantialis aut dimensiones?” (MP IV.I7..., pgs. 424-427), his answer doesn't necessarily alter the status of prime matter as the real, but non-actual, ground of formal reception. Whatever comes first, prime matter must have the reality that Siger grants it to receive either substantial form or dimensions. He does respond that dimensions only have priority in a certain sense. They are not the cause of form simpliciter, but only the cause ad aliquid, i.e., of divisibility. He states: "Dicendum ergo quod, licet dimensiones non sint unde forma inchoat quantum ad esse formae simpliciter, tamen sunt unde divisibilitas sive esse divisibile formae inchoat. Unde sunt causa quantum ad aliquid, et sic primum ordine essendi quantum ad aliquid. Cum autem hic modus quo dimensiones praecedunt formam, non sit modus prioris quo substantia praecedit accidens, ex hoc non sequitur dimensiones esse substantiam." Ibid., pg. 427.

65 "Dicendum quod generatio, communiter accipiendo generationem, et prout est in substantiis et prout est in aliis a substantia, ipsa, dico, ad hoc quod sit ad minus requirit duo, scilicet oppositum, id est privationem formae generandae, et etiam suiectum, quod scilicet transmutetur de uno oppositorum ad aliud oppositum, sicut ARISTOTELES dicit in $I^{\circ}$ Physicorum. Differunt tamen nihilominus generatio in substantia et generatio in 
ter qua matter to explain the continued renewal of potency with every change, a continued renewal or remaining potent that is distinct from the multitude of contrary potencies themselves. And even though this subterranean subject of change cannot be known directly or per se, the account of change must admit such in order to successfully explain change.

Further in the Cambridge Report, in the same question where he discusses the four manners by which matter is understood, Siger asks the verbose question of whether prime passive potency, which is prime matter, is essentially potency, in such a way that potency is the substance of matter. ${ }^{66}$ Once again, he argues that potency is not something pertaining to the essence of matter nor is it predicated essentially of matter. Both Van Steenberghen and McAleer maintain that Siger follows Averroes in distinguishing potency as an accident in the category of relation from potency as first passive potency, and like Averroes identifies the latter as the essence of matter. ${ }^{67}$ For Siger, this distinction arises explicitly

aliis a substantia, quia cum est generatio in substantia, tunc suiectum quod transmutatur non retinet nomen nec rationem quam prius habebat; et cum ratio vel definitio sit secundum formam, non retinet formam et speciem quam prius habebat. Et quod requirat oppositum, id est privationem formae generandae, apparet, quoniam illud quod est non generatur. Si enim debet generari haec forma in aliquo, scilicet musica, oportet quod ille habeat privationem huius formae generandae, scilicet quia sit immusicus, cum nihil transmutetur ad illud quod actu habet et ut etiam habet. Ergo vides quod non esset transmutatio nisi esset oppositum eius quod debet generari in transmutato.” MV VII.5 ..., pg. 393.

${ }^{66}$ MC V.32..., pgs. 26I-264.

${ }^{67}$ Van Steenberghen, McAleer, and Wippel have all noted this Sigerian view on the independence of matter. Van Steenberghen states: "La matière, sujet de la transformation substantielle, pure puissance capable de recevoir toutes les formes, n'est pas négation de l'être ou privation pure: elle a une certaine réalité (babet naturam entis). Mais elle n'est pas de soi intelligible, car c'est la forme qui la rend intelligibile. Ellle fait partie de la quiddité des substances corporelles." Fernand Van Steenberghen: Maître Siger de Brabant, Philosophes Médiévaux Tome XXI, Louvain: Louvian Publications Universitaires I977, pg. 327. He then asks: "La matière s'identifie-t-elle à sa puissance? Si l'on etend par $<<$ puissance $>>$ ce par quoi la matière est déterminable (potest) et ordonnée à la forme, cette puissance s'identifie à la substance de la matière; mais si l'on etend par $<<$ puissance $>>$ l'ordre lui-même ou le rapport à la forme, cette puissance est distincte de la matière, car elle relève de la catégorie de relation (ad aliquid); cette relation et un accident de la matière, comme la privation. La pussance ainsi entendue est d'ailleurs multiple, puisque la matière est ordonnée à toutes les formes et à divers actes." Ibid. McAleer also takes note of the status of matter in Siger's thought. See n. 48 above. In discussing Siger's student Godfrey of Fontaines's position on the relation between matter and potency, Wippel notes an 
only in the Physics. Here he states: "[...] by taking potency for that by which (quo) matter is able and has order to form (pro illo quo materia potest et ordinem babet ad formam), thus potency is the substance of matter. ${ }^{\prime \prime 8}$ Matter's essential nature as potency is that by which it has susceptibility to form. He contrasts this with what we might call the first, or normal, sense of potency as order and relation to form. If, however, we are to maintain with Van Steenbergen and McAleer that Siger identifies the second sense of potency as the essence of matter, we must be careful to qualify what Siger means by this term.

Concerning the essence of matter itself, the first sense of "potency" (i.e., a yet-to-be-enacted actuality), in which "actuality and potency" are correlative terms like "double and half than," ${ }^{69}$ represents an accidental application to matter of a relation abstracted by the intellect from the realm of actuality. ${ }^{70}$

ambiguity within Siger's own view. Although his student is content with embracing the matter as potency thesis, and Siger himself seems to present such a view at points, the non-identity of matter with potency also finds a place in Sigerian physics and metaphysics. See John F. Wippel: The Metaphysical Thought of Godfrey of Fontaines: A Study in Late ThirteenthCentury Philosophy, Washington D.C.: The Catholic University of America Press I98I, pgs. 262-263.

68 "Cum ergo quaeritur utrum materia sit sua potentia, dicendum quod, sumendo potentiam pro illo quo materia potest et ordinem habet ad formam, sic potentia est substantia materiae; sumendo vero potentiam pro ordine et respectu, materia non est ille eius respectus, et sic potentia est ad aliquid, materia vero non.” Physics I. q. 2..., pg. I50.

69 "Dico ad hoc quod materia substantia est, non quidem in actu, sed substantia in potentia. Et hoc apparet per rationes adductas. Ad rationes in oppositum dicendum quod cuius esse substantiale est posse esse, ipsum non est substantia, sed magis ad aliquid. Cuius tamen esse accidentale est posse esse, ipsum potest esse substantia: sicut aliquid cuius esse accidentale est esse duplum essentialiter substantia est. Materiae autem esse substantiale non est posse esse, sed accidentale magis, ut apparet ex determinatis in $V^{\circ}$ huius, ubi dictum est quod potentia est accidens substantiae materiae." MC VII.5 ..., pg. 333.

${ }^{70}$ Potency is an accident of reason. What does he mean by an accident of reason? Such an accident is one procured through the comparison of matter to form. "Sed advertendum est quod non est aliquod accidens reale, ita ut haberet rationem entis si non esset intellectus comparans materiam ad formam. Cuius probatio est quia potentia inest materiae per hoc quod privata est forma, secundum COMMENTATOREM $I^{\circ}$ Physicorum. Reliquum igitur extremum huius habitudinis quae importatur nomine $<<$ potentiae $>>$ non est ens in re, cum sit forma qua privata est materia. Ergo haec habitudo reale accidens non potest esse. Sed nec purum figmentum, ita ut nihil in re ei correspondeat. Immo, cum intelligitur comparatio materiae ad formam, quae significatur nomine $<<$ potentiae $>>$, materia est aliquid conveniens ad talem comparationem; et ex transmutatione 
This might explain why Siger avoids using the term "potentia" in this second sense to identify the nature of matter and instead defines matter as that which is in a middle way between act and potency (in medio modo inter actum et potentiam). ${ }^{7 \mathrm{I}}$ Such a distinction, he argues, is clear by taking account of the name "potency," which suggests a name of order or respect. In terms of matter itself, he states: "Matter, however, is something subsisting through itself according to its own account, and relation to another happens to it; this is why potency happens (accidit) to matter." ${ }^{72}$ Although such an account (ratio) cannot be in the manner of a definition, as definition signifies a formal what it was to be, matter retains its own accountability in terms of explaining a necessary fact about sublunary change, namely that each hylomorphic composite remains potent.

"Potentia" as the essence of matter thus cannot be potency as distinguished from act (i.e., potency in the first sense). These potencies are "used up" (corrumpitur) with the advent of the act, and are defined on the basis of form, opposing each other as contraries. ${ }^{73}$ The essence of matter would be "potency to...," where the ellipsis marks relation to form. As we have seen, matter can successively bear contrary potencies because it is itself distinct from them. Instead, to explain why matter qua matter is able to receive form and why even as a form has been received and the potency enacted, the matter necessarily continues to remain potent and non-identical to form, the essence of matter qua potency might better be called "the power to remain potent." What char-

ad formam comprehendit. Et ideo non quidlibet quod intelligitur comparari ad formam est potentia ad formam, sed quod secundum se est conveniens ad talem comparationem. Nec sequitur quod, si non esset intellectus, materia non transmutaretur ad formam, quia non esset in potentia ad eam, cum sit ens rationis tantum: quia, etsi non esset aliquis intellectus comparans materiam ad formam, ipsa tamen est aliquid secundum naturam suam conveniens ad talem comparationem; et ideo, circumscripta quacumque comparatione intellectus, ipsa transmutaretur ad formam." MC V.32..., pgs. 262-263. It would not have a rationem entis unless the intellect compares form to matter. But neither is it a fiction (figmentum) in such a way that nothing in re corresponds to it. Even without the intellect, matter per se would still agree with the comparison.

${ }^{71}$ MC VII 6..., pg. 335.

72 "Dico ad hoc quod potentia non est aliquid pertinens ad essentiam materiae, nec est praedicatum essentiale de materia, quod apparet inspicienti ad rationem nominis: est autem nomen ordinis sive respectus. Unde et hic definitur per esse principium, quod est aliquid respectivum. Et hoc quod dicit COMMENTATOR, quod potentia est eorum quae dicuntur ad aliquid per rationem suam. Materia autem est aliquid per se subsistens per rationem suam, et accidit ei respectus ad aliud; quare accidit ei potentia. Et hoc magis probatum fuit superius, capitulo De causa." MC V.32.., pg. 262.

${ }^{73}$ See, for example, n. 50 above. 
acterizes matter qua matter is that even as its potencies are formally enacted, matter itself is not used up or-like in the case of celestial bodies-completely informed, but instead, each new composite substance remains potent. ${ }^{74}$ To explain the necessary continuity of change, however, such a "remaining potent" of hylomorphic substances must be attributed to the power of matter qua matter, that is to its essential nature as the power to remain potent.

Even if matter qua matter itself is not actual apart from its relation to form (i.e., as informed and potentially informed), it is real insofar as it is that power by which matter remains potent to a multitude of distinct and contrary forms. Nor is this power a lack or privation on the part of matter. Matter does not merely suffer (patiens tantum) the effect of another's activity, but is the power to bear a multitude of diverse and contrary forms in succession because it resists complete identification with any one form, but continually remains potent. Like the prime mover, whose power to remain active ensures the continuity of motion, what it means to call matter qua matter "the power to remain potent" is that matter both can bear the forms introduced by an agent, and yet remain non-identical to such forms, but necessarily open to new potencies. The subject of this change, Siger argues, is universally distinct from the either of the terms: matter is something distinct from form and privation of form. The power to remain potent must be distinguished from potency as relation to form because if it is to explain why matter (either secondary or primary) is susceptible to form, it cannot explain such susceptibility in terms of form itself or relation to form. This would be to say: prime matter becomes water because it is in potency to water; that is, it has the form of water because it has a potential for the form of water. Such an explanation, however, does not tell us why matter receives such forms except for the fact some agent has imposed this form upon the matter. Instead, Siger argues that forms are not made or produced in matter, but educed or extracted according to matter's own inchoate susceptibility to form. To take seriously this Arisotelian-Averrosian sentiment of the agent as extractor not producer of form, we must think through our understanding of matter itself. ${ }^{75}$

Thus, by calling into question the traditional image of matter, Siger can understand change as more than the forceful imposition of form upon a passive medium, but instead a collaborative eduction or extraction toward which matter makes a real contribution. Matter contributes to this process such that with

${ }^{74}$ Although Aquinas at times also uses this language, he does not think through how matter through its own power remains in potency and is not conquered by form. See SCG II. 30 .

${ }^{75}$ MC V.I6..., pg. 223. 
each bearance of a form, insofar as matter resists complete identification with that form, it remains in potency to other and contrary forms. ${ }^{76}$ Instead, the fact that each new hylomorphic composite has been generated from the destruction of another, and it itself will be corrupted with another necessarily being generated, could only be stated an accidental fact. It just so happens that no form gains a strong enough hold over its byle to block the advances of another agent's imposition of form. ${ }^{77}$ Such a power provides instead a necessary principle in explaining the structure of change as we experience it. Without such an underlying subject of change, we could offer no account of the necessity of generation and corruption.

In a very loose sense, each hylomorphic being is a plurality of "things" because its matter retains traces of its formal past and future, those things that is has been and those things which it can become. It is the matter, and not the form, of the hylomorphic composite that remains inherently open (i.e., qua its nature) to contrary forms and thereby exposes each individual to the necessity of change. Hylomorphic substances do not become mere heaps, or accidental unions between form and matter, because even when matter's desire for another substantial form is fulfilled and the composite undergoes corruption, the same matter remains. There is continuity of change on account of matter. Such continuity is not only between past and present- that is, what was once this, is now that - but also toward the future insofar as matter's remaining potent necessarily entails that the fulfillment of any given potency will be met with openness to new potencies and their future fulfillment. Matter thus retains traces of both its former and future potencies. For this, it needs the minimal degree of reality which Siger has granted it.

\section{Conclusion}

Does not a return to prime matter risk plunging philosophy back into theogonal mythos where all emerges from a dark and indeterminate abyss, like Hes-

${ }^{76}$ For a discussion of this real contribution of "bearance and resistance" as a necessary correlate of activity in the thought of Aristotle, see Martin Heidegger: Aristotle's Metaphysics j I-3: On the Essence and Actuality of Force, trans. Walter Brogan and Peter Warnek, Bloomington: Indiana University Press I995, pgs. 73-87.

77 As is the case with Aquinas, prime matter is pure passivity and contributes nothing of its own to the process of change. Of prime matter, he states: "[id] est aliquid quod est motum et patiens tantum." See n. 4 above. Thus, the fact that it continues to remain potent is merely an accidental fact of those agents acting upon it and not something intrinsic to its own nature. 
iod's Night? Such can recount the generations of gods and mortals from chaos, but fails to rationally explain such procession. As one contemporary scholar states: "For all serious scientific philosophy and physics the doctrine of First Matter, or prima materia, has, after a long and illustrious life, died quietly and ignobly $[. ..] . "{ }^{78}$ Are we not unnecessarily resurrecting a metaphysical corpse?

If we are to take seriously Siger's argument for matter's real contribution to change, then the answer must be "no." By critiquing the image of matter as the "stuff for" artificial production as available for active agents to work-upon, Siger has not only thought-through the conditions for this familiar functional manifestation of matter within our everyday experience, but also called into question the deeply rooted ontological corollary of such a view: namely, matter is nothing more than the abstract sum of its formal relations. By showing that although appearing as and in relation to form, matter qua matter cannot be reduced to such a relational identity, Siger has not simply posited "a dark abysmal Night" beyond the reach of rational thought. Instead, he has shown that what grounds the terms of change cannot be accounted for by the terms themselves: if we seek an account of the necessity that every corruption will be met with a new generation, itself open to corruption but also further generation, we must look beyond — or perhaps between — the formal terms of the series. But if matter were nothing more than that upon which form has been imposed, itself united only by a series of conquering powers, our philosophical account could not speak to the necessity of continuous generation and corruption. Instead, by necessity and according to its own power, matter opens itself to new forms. Whereas matter according to the traditional description only abstractly adds together disparate relations-much like a single mirror abstractly unites a series of reflected images - according to Siger's account, matter's own fundamental nonidentity to form allows it to receive form, but also to inherently remain open to new forms. This, according to Siger, saves our explanatory framework. Why is there continuity in our experience of change? Because underlying even the most radical change (i.e., generation and corruption), a real subject distinct from the terms of change remains. What is this subject? It is that by which (quo) formal relations are subsequently enacted without which all change would be a disparate series of forceful impositions and occupations lacking the continuity which we experience in change. It is the power to remain potent.

${ }^{78}$ Hugh R. KING: "Aristotle without Prima Materia”, Journal of the History of Ideas, XVII3 (Jun., I956), pg. 370.

Tópicos 39 (20I0) 